\title{
Gasoline Prices, Government Support, and the Demand for Hybrid Vehicles in the U.S.*
}

\author{
Arie Beresteanu and Shanjun $\mathrm{Li}^{\dagger}$
}

First Version: August, 2007

This Version: January, 2008

\begin{abstract}
Exploiting a rich data set of new vehicle registrations in 22 U.S. Metropolitan Statistical Areas from 1999 to 2006, we analyze the determinants in the demand for hybrid vehicles and examine government programs that aim to promote the adoption of hybrid vehicles. We find that both the recent run-up in gasoline prices from 1999 and federal income tax incentives are important in the diffusion of hybrid vehicles, explaining about $14 \%$ and $27 \%$ hybrid vehicle sales in 2006 , respectively. We compare the current income tax credit program with a rebate program and find that the rebate program needs less government revenue to achieve the same level of average fuel-efficiency of new vehicles. The cost advantage of such a rebate program is bigger with larger incentives.
\end{abstract}

${ }^{*}$ We thank Paul Ellickson, Han Hong, Wei Tan, and Chris Timmins for their helpful comments. Financial support from Micro-Incentives Research Center at Duke University is gratefully acknowledged.

${ }^{\dagger}$ Arie Beresteanu, Assistant Professor, Department of Economics, Duke University, Durham, NC 27708-0097, arie@econ.duke.edu; Shanjun Li, Asssitant Professor, Department of Economics, SUNY-Stony Brook, Stony Brook, NY 11794-4384, shlli@notes.cc.sunysb.edu. 


\section{Introduction}

Since their introduction into the U.S. market in 2000, hybrid vehicles have been in increasingly strong demand: sales grew from less than 10,000 cars in 2000 to more than 250,000 in 2006. A hybrid vehicle combines the benefits of gasoline engines and electric motors and delivers better fuel economy than its non-hybrid equivalent. Therefore, the hybrid technology has been considered as a promising tool in the U.S. to reduce $\mathrm{CO}_{2}$ emission and air pollution and to achieve energy security. Following the recommendation of the National Energy Policy Report $(2001),{ }^{1}$ the U.S. government has been supporting consumer purchase of hybrid vehicles in the forms of federal income tax deductions before 2006 and federal income tax credits since then.

An active governmental role to support the diffusion of this technology can be justified on the ground of environmental externalities and national energy interest: the adoption of hybrid vehicles by U.S. drivers could be too low compared with the socially optimal level because the individual benefit of driving a hybrid vehicle (relative to a conventional vehicle) is smaller than the social benefit. The discrepancy between the individual benefit and the social benefit can be further magnified by the high initial production cost of hybrid vehicles due to the presence of significant economies of scale inherent in the automobile manufacturing industry and by information spillovers among consumers and among firms often present in the diffusion process of new technologies. ${ }^{2}$

The United States is increasingly dependent on foreign oil: the proportion of imports in total petroleum products has reached 60 percent in recent years, largely driven by growing motor gasoline consumption. Moreover, while producing an estimated 60 to 70 percent of total urban air pollution and 25 percent of total emission of smog-forming

\footnotetext{
${ }^{1}$ The report was written by the National Energy Policy Development (NEPD) Group established in 2001 by George W. Bush. The goal of the group is to develop a national energy policy designed to promote dependable, affordable, and environmentally sound production and distribution of energy for the future.

${ }^{2}$ Stoneman and Diederen (1994) argues for more government attention to technology diffusion citing the presence of imperfect information and externalities. Jaffe and Stavins (1999) focus on the gradual diffusion of energy-conservative technologies and suggest the use of both economic incentives and direct regulations.
} 
pollutants, motor vehicles account for about 20 percent of the annual U.S. emissions of carbon dioxide, the predominant greenhouse gas that contributes to global warming. To address energy security and environmental problems, different policies have been proposed such as increasing the federal gasoline tax, tightening Corporate Average Fuel Economy (CAFE) Standards, and promoting the development and adoption of fuel-efficient technologies including the hybrid technology and the fuel cell technology. Many studies have examined the first two alternatives, with the majority of them finding that increasing the gasoline tax is more cost-effective than tightening CAFE standards. ${ }^{3}$ However, there exist few studies that look at the adoption of hybrid technology and none of them examines the effect of government support on solving energy dependence and environmental problems through the diffusion of hybrid vehicles.

In this paper, we analyze the determinants of hybrid vehicle purchase, paying particular attention to recent rising gasoline prices and government support. We investigate how effective government support has been in promoting hybrid vehicle adoptions and to what extent the hybrid technology can help the United States reduce gasoline consumption and $\mathrm{CO}_{2}$ emissions. In addition, we examine the cost-effectiveness of the current income tax credit program by comparing it with a rebate program. As outlined in the Energy Policy Act of 2005, income tax credits exist to encourage the adoption of qualified energy-efficient home improvement appliances, fuel-efficient vehicles, solar energy system, and fuel cell and microturbine power systems. In the case of hybrid vehicles, the income tax credit reduces the regular federal income tax liability of the hybrid vehicle buyer, but not below zero. ${ }^{4}$ Therefore, households whose income tax liability is smaller than the tax credit are not able to enjoy the maximum possible incentive. Nevertheless, these households tend to have low income and be more responsive to the incentives than high-income households. A rebate program that offers equal subsidy to all the buyers of the same hybrid model, therefore,

\footnotetext{
${ }^{3}$ See for example, National Research Council (2002); Congressional Budget Office (2003); Austin and Dinan (2005); Bento, Goulder, Henry, Jacobsen, and von Haefen (2005) ; and West and Williams (2005).

${ }^{4}$ The tax credit cannot be carried over to the future. Moreover, the credit will not reduce alternative minimum tax (AMT) when it applies to a hybrid vehicle buyer.
} 
may result in more hybrid sales than the tax credit program with the same amount of total government subsidy. The better cost-effectiveness of a rebate program should also hold in the income tax credit program for other energy-efficient products aforementioned.

Taking advantage of a rich data set of new vehicle registrations in 22 Metropolitan Statistical Areas (MSA) from 1999 to 2006, we estimate a market equilibrium model with both a demand side and a supply side in the spirit of Berry, Levinsohn, and Pakes (1995) (henceforth BLP). The demand side is derived from a random coefficient utility model and the supply side assumes that multiproduct firms engage in price competition. Similar to Petrin (2002) and Berry, Levinsohn, and Pakes (2004), our estimation employs both aggregate market-level sales data and household-level data. We use the 2001 National Household Travel Survey (2001 NHTS) to augment aggregate sales data. Different from these studies, we observe the sales of the same model in 22 markets and use product fixed effects to control for price endogeneity due to unobserved product attributes. Therefore, our estimation method does not rely on the maintained exogeneity assumption of observed product attributes to unobserved product attributes, which is used to form moment conditions in the literature.

Based on the structural parameter estimates, we first conduct counterfactual simulations to evaluate the effect of rising gasoline prices and government support on the demand for hybrid vehicles in the 22 MSAs. We find that both factors are significant in explaining the increasing popularity of hybrid vehicles. However, due to the small market share of hybrid vehicles, the reduction in both gasoline consumption and $\mathrm{CO}_{2}$ emission resulted from government support on hybrid vehicle purchases has been inconsequential. With the increasing number of hybrid models introduced into the market and increasing market share of hybrid vehicles, government support should be able to make more significant contribution toward achieving oil independence and environmental objectives. We then compare the federal income tax credit program in 2006 with a rebate program in terms of their cost-effectiveness. We find that the rebate programs costs less government revenue to achieve the same average fuel-efficiency of new vehicle fleet in 2006, suggesting that rebate 
programs should be favored over income tax credit programs to promote the adoption of energy-efficient products.

Three recent papers have examined several issues related to hybrid vehicles. Kahn (2008) studies the effect of environmental preference on the demand for green products and finds a positive correlation between the adoption of hybrid vehicles and the percentage of registered green party voters in California. Sallee (2008) studies incidence of tax credits for Toyota Prius and shows that consumers capture the significant majority of the benefit from tax subsidies. A more closely related study to ours, Gallagher and Muehlegger (2007) estimate the effect of state and local incentives, rising gasoline prices, and environmental ideology on hybrid vehicle sales and find all three very important. A major difference between our study and these papers is that all of them focus on a single hybrid model or hybrid vehicles alone while we take a structural method to estimate an equilibrium model of U.S. automobile market. Our empirical model allows us to simulate what would happen to the whole market under different scenarios (e.g., under a different federal support scheme) and to examine the response in the demand side and the supply side separately.

The remainder of this paper is organized as follows. Section 2 describes the background of the study and data used. Section 3 lays out the empirical model and the estimation strategy. Section 4 provides the estimation results. Section 5 conducts simulations and section 6 concludes.

\section{Industry Background and Data}

In this section, we first present a brief introduction of the hybrid technology, the market of hybrid vehicles in the U.S., and the government support on the technology. We then discuss the data used.

\section{$2.1 \quad$ Background}

The current state of fuel economy and emissions produced by a typical automobile is largely a reflection of low efficiency of conventional internal combustion engines: only 
about 15 percent of the energy from the fuel consumed by these engines gets used for propulsion, and the rest of the energy is lost to engine and driveline inefficiencies and idling. Hybrid vehicles combine power from both a gasoline engine and a electric motor that runs off the electricity from a rechargeable battery. The battery harnesses some of the energy that would be wasted in operations in a typical automobile (such as energy from braking) and then provides power whenever the gasoline engine proves to be inefficient and hence is turned off. ${ }^{5}$

Toyota introduced the first hybrid car, Toyota Prius, in Japan in 1997. In 2000, Toyota and Honda introduced their hybrid vehicles, Toyota Prius and Honda Insight, into the U.S. market. With rising gasoline prices, hybrid vehicles have enjoyed an increasing popularity in recent years. In 2004, as the first U.S. manufacturer into the hybrid market, Ford introduced its first hybrid model. In 2007, GM and Nissan entered the competition by introducing their own hybrid models. Table 1 shows the number of hybrid models and the sales history from 2000 to 2006. The number of hybrid models increased from 2 to 10 during this period. ${ }^{6}$ The most popular hybrid model, Toyota Prius, accounted for 59 percent of the total new hybrid sales in 2000 and 42 percent in 2006.

Because of the improved fuel economy and reduced emissions, the hybrid technology is considered as a promising technology by the National Energy Policy Report (2001), which concludes that the demand for hybrid vehicles must be increased in order to achieve economies of scale so as to bring the cost of hybrid vehicles down. The group recommended in the report that an efficiency-based income tax incentives be available for purchase of new hybrid vehicles. These tax incentives can help to offset the higher cost of hybrid

\footnotetext{
${ }^{5}$ Another technology, the fuel cell technology represents a more radical departure from vehicles with internal combustion engines. They are propelled by electricity created by fuel cells onboard through a chemical process using hydrogen fuel and oxygen from the air. This emerging technology holds the potential to dramatically reduce oil consumption and harmful emissions. However, fuel cell vehicles are not soon expected to be commercially viable.

${ }^{6}$ There are 19 hybrid models available in 2007. According to J.D. Power and Associates, there could be 44 hybrid models in the United States by 2012 .
} 
Table 1: History of Hybrid Vehicles

\begin{tabular}{ccrcc}
\hline \hline Year & $\begin{array}{c}\text { No. of hybrid } \\
\text { models offered }\end{array}$ & Hybrid sales & $\begin{array}{c}\text { New vehicle } \\
\text { sales }\end{array}$ & $\begin{array}{c}\text { Percent of } \\
\text { hybrid }\end{array}$ \\
\hline 2000 & 2 & 9,367 & $17,410,320$ & 0.054 \\
2001 & 2 & 20,287 & $17,177,789$ & 0.118 \\
2002 & 3 & 35,961 & $16,847,211$ & 0.213 \\
2003 & 3 & 47,525 & $16,675,648$ & 0.285 \\
2004 & 4 & 83,153 & $16,912,613$ & 0.492 \\
2005 & 8 & 209,711 & $16,997,182$ & 1.234 \\
2006 & 10 & 251,864 & $16,559,970$ & 1.521 \\
\hline
\end{tabular}

vehicles compared to their non-hybrid counterparts. ${ }^{7}$ Following the recommendation, the government has provided a "clean fuel" tax deduction of up to $\$ 2,000$ for new hybrid vehicles placed in service during 2001 to 2005. The Energy Policy Act of 2005 replaced the income tax deduction with an income tax credit of up to $\$ 3,400$ for vehicles purchased after December 31, 2005. The tax credit for each model varies and is based on the improvement in fuel economy provided by that model relative to the non-hybrid counterpart. The credit begins to phase out over five subsequent calendar quarters for vehicles once the manufacturer sells a total of 60,000 eligible hybrid vehicles starting from January $1,2006 .^{8}$ In addition, some state and local governments provide benefits to hybrid buyers such as state income tax deduction/credit, sale tax exemption, High-Occupancy-Vehicle (HOV) lane privileges and free parking.

${ }^{7}$ A 2005 report by Edmunds.com finds that a hybrid model can cost about $\$ 4,000$ more on average than its equivalent non-hybrid model in terms of purchase price plus ownership costs over the first five years. For example, a Toyota Prius costs $\$ 5,283$ more than a Toyota Corolla. However, with the average MPG increases from 35 to 55 MPG, the saving in fuel cost is only about $\$ 2,340$ over the first five years, assuming annual travel of 15,000 miles and gasoline being $\$ 3.00$ per gallon.

${ }^{8}$ In the second and third calendar quarter after the calendar quarter in which the manufacturer reaches the 60,000 mark, tax credits for hybrid models by this manufacturer become $50 \%$ of their original amounts. They are then reduced to $25 \%$ in the fourth and fifth calendar quarter and to zero thereafter. Toyota reached the 60,000 mark in June 2006. From October 1, 2006 to the end of March, 2007, hybrid vehicles by Toyota are only eligible for $50 \%$ of original tax credits. 


\subsection{Data}

There are three data sets used in this study. The first one, from annual issues of Automotive News Market Data Book, contains characteristics and number of sales of virtually all new vehicles sold in the U.S. from 1999 to $2006 .{ }^{9}$ Table 2 reports summary statistics of these variables. Price is the manufacturer suggested retail prices (MSRP). Size measures the "footprint" of a vehicle. Miles per gallon (MPG) is the weighted harmonic mean of city MPG and highway MPG based on the formula provided by EPA to measure the fuel economy of the vehicle: $\mathrm{MPG}=\frac{1}{0.55 / \text { city MPG }+0.45 / \text { highway MPG }}$. There are four types of vehicles in the data set: car, van, SUV, and pickup truck. They are further classified into 15 segments based on product attributes and market orientations.

Table 2: New vehicle sales and characteristics

\begin{tabular}{lccccc}
\hline \hline & Mean & Median & Std. Dev. & Min & Max \\
Quantity ('000) & 78.9 & 45.3 & 104.5 & 2.1 & 939.5 \\
Price (in '000 \$) & 30.1 & 26.4 & 14.2 & 10.3 & 98.9 \\
Size(in '000 inch ${ }^{2}$ ) & 13.5 & 13.4 & 1.6 & 8.3 & 18.9 \\
Horsepower & 195 & 190 & 59 & 55 & 405 \\
MPG & 22.4 & 22.0 & 5.2 & 13.2 & 64.7 \\
\hline
\end{tabular}

The second data set contains the number of sales for these vehicles in 22 MSAs during this period. Accounting for about $15.3 \%$ of total U.S. vehicles sales, these MSAs are chosen from different census regions and have large variations in terms of size and average household demographics. ${ }^{10}$ This data set describes aggregated consumer purchase decisions in different areas over time. Table 3 presents the total new vehicle sales, the percentage of hybrid vehicles, the availability of local and state incentives, and gasoline prices in 2006. The percentage of hybrid vehicles in total new vehicle sales is highest in San Francisco and lowest in Miami among the 22 MSAs. The average hybrid share is 2.86 percent in the MSAs with local incentives while the average hybrid share is only 1.75 percent in the

\footnotetext{
${ }^{9}$ Exotic models with tiny market shares such as Farrari are excluded.

${ }^{10}$ The geographic coverage for each MSA is based on the 1999 definition by the Office of Management and Budget. For Albuquerque, NM and Little Rock, AR, we have sales data only from 2001 to 2006.
} 
Table 3: Hybrid sales and local incentives in 2006

\begin{tabular}{lrrclc}
\hline \hline MSA & $\begin{array}{r}\text { Number of } \\
\text { households }\end{array}$ & $\begin{array}{r}\text { Hybrid } \\
\text { sales }\end{array}$ & $\begin{array}{c}\text { Percent in total } \\
\text { vehicle sales }\end{array}$ & $\begin{array}{l}\text { Local incentive } \\
\text { (start date) }\end{array}$ & $\begin{array}{c}\text { Gasoline } \\
\text { price } \$\end{array}$ \\
\hline Albany, NY & 360,273 & 737 & 1.62 & Income tax $(03 / 04)$ & 2.70 \\
Albuquerque, NM & 319,922 & 763 & 2.37 & Excise tax (07/04) & 2.58 \\
Atlanta, GA & $1,994,938$ & 2,775 & 1.34 & No & 2.52 \\
Cleveland, OH & $1,167,916$ & 1,643 & 1.16 & No & 2.51 \\
Denver, CO & $1,132,085$ & 3,561 & 3.51 & Income tax $(01 / 01)$ & 2.45 \\
Des Moines, IA & 209,297 & 438 & 1.96 & No & 2.32 \\
Hartford, CT & 704,130 & 1,535 & 2.00 & Sales tax $(10 / 04)$ & 2.80 \\
Houston, TX & $2,197,010$ & 3,132 & 1.22 & No & 2.49 \\
Lancaster, PA & 197,929 & 318 & 1.80 & No & 2.53 \\
Las Vegas, NV & 713,397 & 1,340 & 1.32 & No & 2.62 \\
Little Rock, AR & 250,142 & 436 & 1.50 & No & 2.48 \\
Madison, WI & 185,657 & 917 & 4.88 & No & 2.55 \\
Miami, FL & $1,706,995$ & 2,322 & 0.87 & HOV $(07 / 03)$ & 2.64 \\
Milwaukee, WI & 682,896 & 1,340 & 1.99 & No & 2.59 \\
Nashville, TN & 548,192 & 752 & 1.47 & No & 2.43 \\
Phoenix, AZ & $1,585,544$ & 3,254 & 1.53 & No & 2.51 \\
St. Louis, MO & $1,100,071$ & 1,526 & 1.30 & No & 2.40 \\
San Antonio, TX & 739,674 & 1,022 & 1.25 & No & 2.41 \\
San Diego, CA & $1,177,384$ & 4,946 & 3.40 & HOV $(08 / 05)$ & 2.85 \\
San Francisco,CA & $2,871,199$ & 20,162 & 7.02 & HOV $(08 / 05)$ & 2.87 \\
Seattle, WA & $1,529,146$ & 5,732 & 3.82 & Sales tax $(01 / 05)$ & 2.70 \\
Syracuse, NY & 292,717 & 408 & 1.15 & Income tax $(03 / 04)$ & 2.69 \\
\hline
\end{tabular}

MSAs without local incentives.

Based on these market-level sales data, we estimate a linear regression to examine the correlation between MSA characteristics and hybrid sales. The dependent variable is the share of hybrid vehicles among the total sales of all new vehicles. Mean eduction is the average education level of the household head in the MSA. Local incentive is a dummy variable capturing whether there are state and local incentives available. Tax credit is essentially a dummy variable for year 2006 in which federal tax credits replaces tax discounts for hybrid buyers.

The coefficients of all the variables except the local incentive dummy are significant at the $5 \%$ significance level (the standard errors are cluster standard errors where a cluster is an MSA). All the variables have positive effects on hybrid sales. The regression results 
Table 4: OLS regression of hybrid shares

\begin{tabular}{lcc}
\hline \hline Variable & Para. & Std. Err. \\
\hline Constant & -9.495 & 1.396 \\
Mean income & 0.252 & 0.093 \\
Gas price & 0.835 & 0.107 \\
Mean education & 0.575 & 0.141 \\
Trend & 0.136 & 0.037 \\
Local incentive & 0.255 & 0.209 \\
Tax credit & 0.566 & 0.074 \\
\hline No. of obs. & 172 & \\
R-squared & 0.715 & \\
\hline
\end{tabular}

suggest that areas with higher gasoline prices have stronger hybrid demand. Consumers with higher income and more education are more likely to buy hybrid vehicles. To the extent that many consumers buy hybrids to make a statement about their conviction of environmental protection, people with higher income and more education may have more resources and awareness to do so. The coefficient on Trend captures the fact that the demand for hybrids is stronger over time, ceteris paribus. The coefficient on Local incentives is intuitively signed but insignificant. ${ }^{11}$ Tax credits, which represent stronger government support than tax discounts available before 2006, do increase hybrid sales.

As discussed above, our first data set describes vehicle choices consumers face while the second data set presents consumer purchase decisions at the aggregate level in the 22 MSAs. However, the link between household demographics and consumer choice is missing. The third data set, the 2001 National Household Travel Survey (2001 NHTS), helps relate household demographics to purchase decisions. The survey was conducted by agencies of the Department of Transportation from March 2002 through May 2003. This data set provides detailed household level data on vehicle stocks, travel behavior and household demographics at the time of survey. There are 69,817 households and 139,382 vehicles in the data. Among all the surveyed households, 45,984 are from MSAs.

\footnotetext{
${ }^{11}$ If local incentives are set in response to unobserved local factors that affect hybrid vehicle purchases, the coefficient on local incentives cannot be interpreted as the effect of local incentives on hybrid vehicle demand.
} 
Table 5: Average household demographics

\begin{tabular}{lcccccc}
\hline \hline & All & \multicolumn{4}{c}{ Households who purchase } \\
\cline { 3 - 7 } & & New & Car & Van & SUV & Pickup \\
\hline Household size & 2.55 & 2.88 & 2.67 & 3.81 & 3.02 & 2.84 \\
Renter & 0.364 & 0.211 & 0.266 & 0.090 & 0.147 & 0.163 \\
Children dummy & 0.336 & 0.402 & 0.328 & 0.696 & 0.499 & 0.352 \\
Age of household head & 48.83 & 46.89 & 48.07 & 46.24 & 44.19 & 46.25 \\
Time to work (minutes) & 17.90 & 20.92 & 20.49 & 19.75 & 19.73 & 24.00 \\
\hline
\end{tabular}

Table 6: New vehicle purchase probability

\begin{tabular}{lc}
\hline \hline Income ('000) & Purchase probability \\
\hline$<15$ & 0.0020 \\
{$[15,25)$} & 0.0440 \\
{$[25,50)$} & 0.1125 \\
{$[50,75)$} & 0.1728 \\
{$[75,100)$} & 0.1972 \\
$\geq 100$ & 0.2574 \\
All households & 0.1304 \\
\hline
\end{tabular}

Column 2 in Table 5 shows the means of several demographics for households living in MSAs. Renter, a dummy variable, equals 1 for the households that living in rented houses and 0, otherwise. Children dummy, also a dummy variable, is 1 for households with children. Columns 3 to 7 present the means of household demographics for different groups based on household vehicle choice. These conditional means provide additional moment conditions in our estimation where we match the predicted moments from the empirical model to these observed moments. As household incomes are categorized and top-coded at $\$ 100,000$, we provide the probability of new vehicle purchase for six income groups in Table 6. In our estimation of the empirical model, these conditional probabilities are matched by their empirical counterparts. 


\section{Empirical Model and Estimation}

In this section, we discuss our empirical model and estimation strategy. Our empirical model closely follows recent empirical literature on differentiated products (e.g., BLP, Petrin (2002), Berry et al. (2004)). The empirical model includes both a demand side and a supply side. Vehicle demand is derived from a random coefficient discrete choice model. A household makes a choice among all new models and an outside alternative to maximize household utility in each year. We use their aggregated decision outcomes (product sales in this case) to recover consumer preference parameters. The supply side assumes that multiproduct firms engage in Betrand competition (taking product choices as given). The first-order conditions of firm profit maximization allow us to recover the marginal cost for each product. In a counterfactual analysis, we then base the recovered marginal cost and the oligopolistic supply curve to solve for new equilibrium prices. We discuss each part separately.

\subsection{Demand Side}

Household's utility from a product is a function of household demographics and product characteristics. Let $i$ denote a household and $j$ denote a product. A household chooses one product from a total of $J$ models of new vehicles and an outside alternative in a given year. The outside alternative captures the decision of not purchasing any new vehicle in the current year. To save notation, we suppress the market index $m$ and time index $t$, bearing in mind the choice set can vary across markets and years. The utility of household $i$ from product $j$ (in market $m$ at year $t$ ) is defined as

$$
u_{i j}=v\left(p_{i j}, X_{j}, \xi_{j}, y_{i}, Z_{i}\right)+\epsilon_{i j}
$$

where $p_{i j}$ is the price of product $j$ for household i. The price is computed based on the MSRP, the sales tax and federal income tax incentives for hybrid vehicles. ${ }^{12} X_{j}$ is a vector

\footnotetext{
${ }^{12}$ MSRPs, also known as "sticker prices", are set by manufacturers and are generally constant across locations and within a model year. Although individual transaction prices are desirable in the analysis
} 
of observed product attributes, $\xi_{j}$ the unobserved product attribute, $y_{i}$ the income of household $i$, and $Z_{i}$ is a vector of household demographics. $\epsilon_{i j}$ is a random taste shock that has type one extreme value distribution. The specification of the first term in the utility function is assumed to be:

$$
v_{i j}=\alpha_{i} \frac{p_{i j}}{y_{i}}+\sum_{k=1}^{K} x_{j k} \tilde{\beta}_{i k}+\xi_{j}
$$

We allow $\alpha$ to vary according to the income group of the household. $x_{j k}$ is the $k$ th product attribute for product $j$. $\tilde{\beta}_{i k}$ is the random taste parameter of household $i$ over product attribute $k$, which is a function of household demographics including those observed by econometrician $\left(z_{i r}\right)$ and those that are unobserved $\left(\nu_{i k}\right)$ :

$$
\tilde{\beta}_{i k}=\bar{\beta}_{k}+\sum_{r=1}^{R} z_{i r} \beta_{k r}+\nu_{i k} \beta_{k}^{u}
$$

The utility of the outside alternative $(j=0)$ is specified as

$$
v_{i 0}=Z_{i} \beta_{0}+\nu_{i 0} \beta_{0}^{u}+\epsilon_{i 0},
$$

where $\nu_{i 0}$, the unobserved household demographics, captures different valuations of the outside alternative by different households due to heterogeneity in vehicle holdings and transportation choices.

Based on the utility function, we can derive the aggregate demand function. Define $\theta$ as the vector of all preference parameters. The probability that the household $i$ chooses choice $j \in\{0,1,2, \ldots, J\}$ is

$$
\operatorname{Pr}_{i j}=\operatorname{Pr}_{i}\left(j \mid p, X, \xi, y_{i}, Z_{i}, \theta\right)=\int \frac{\exp \left(v_{i j}\right)}{\sum_{h=0}^{J} \exp \left(v_{i h}\right)} d F\left(\nu_{i}\right),
$$

of automobile demand given that different consumers may pay different prices for the same model, these data are not easily available. MSRPs have been commonly used in this literature. 
where $p$ is the vector of prices of all products. $\nu_{i}$ is a vector of unobserved demographics for household $i$. The market demand for choice $j$ for a price vector $p$ is then

$$
q_{j}=q(j \mid p, X, \xi, \theta)=\sum_{i} P r_{i j}
$$

\subsection{Supply Side}

The demand side parameters can be estimated without a supply side model. However, a supply side model is needed for the counterfactual analysis where we solve for the prices in a new equilibrium based on firms' price-setting rules derived from the profit maximization problem. Firms are assumed to engage in Betrand competition to maximize the period profit from the whole U.S. market while taking the product mix as given.

The period total variable profit (total revenue minus total variable cost) of a multiproduct firm $f$ is

$$
\pi^{f}=\sum_{j \in \mathcal{F}(f)}\left[p_{j} q_{j}(p, \theta)-v c_{j}\left(q_{j}\right)\right]
$$

where $\mathcal{F}(f)$ is the set of products produced by firm $f \cdot p_{j}$ is the price and $q_{j}$ is the sales for product $\mathrm{j} \cdot v c_{j}$ is the total variable cost of product $j .{ }^{13}$

$$
\sum_{h \in \mathcal{F}}\left[p_{h}-m c_{h}\left(q_{j}\right)\right] \frac{\partial q_{h}(p, \theta)}{\partial p_{j}}+q_{j}(p, \theta)=0
$$

The equilibrium price vector is defined, in matrix notation, as

$$
p=m c(q)+\Delta^{-1} q(p, \theta)
$$

\footnotetext{
${ }^{13}$ We do not consider the role of the CAFE constraints on firms' pricing decision here. See Jacobsen (2007) for an examination of how firms, particularly U.S. firms underprice their fuel-efficient vehicles in order to meet the CAFE standards. In recent years, the CAFE constraints have not been binding for Toyota and Honda who produces the majority of the hybrid vehicles.
} 
where the element of $\Delta$ is

$$
\Delta_{j r}= \begin{cases}-\frac{\partial q_{r}}{\partial p_{j}} & \text { if product } j \text { and } r \text { produced by same firm } \\ 0 & \text { otherwise. }\end{cases}
$$

Equation (9) underlies the pricing rule in a multiproduct oligopoly: equilibrium prices are equal to marginal costs plus markups, $\Delta^{-1} q(p, \theta)$. The implied marginal costs can be computed following $m c=p-\Delta^{-1} q$, where $p$ and $q$ are the observed prices and sales. In a counterfactual analysis, the fixed point of equation (9) can be used to compute new price equilibrium corresponding to a change in the demand equation $q(p, \theta)$, providing that we know the relationship between $m c$ and $q$. Constant marginal cost assumption has been commonly used in recent literature on estimating automobile market equilibrium (for example, Bresnahan (1987); Goldberg (1995)). ${ }^{14}$ If marginal costs are not constant with respect to the total output level, the functional relationship between the two has to be recovered in order to find new equilibrium prices in counterfactual scenarios.

\subsection{Estimation}

The preference parameters in the utility function are estimated by matching the predicted market sales as shown in equation (6) with observed sales in each market. The predicted market sales are computed based on a random sample of households from the 2000 Census data while taking into account various government support programs for hybrid vehicles. Because the federal incentives for hybrid vehicles are in the forms of income tax deductions or income tax credits, they may vary across households depending on household tax liabilities: households with fewer tax liabilities tend to enjoy less tax benefit from buying a hybrid vehicle. To figure out tax incentives for each household, we calculate household income tax liabilities using NBER's online software TAXSIM (version 8.0). TAXSIM takes household income sources and other demographics from survey data as input and returns

\footnotetext{
${ }^{14}$ The constant marginal cost assumption does not reject the existence of economies of scale. A high fixed cost and constant marginal cost can still result in economies of scale.
} 
tax calculations as output. ${ }^{15}$

To illustrate our estimation strategy, which exploits the fact that we observe the demand for each product in many MSAs, we bring the market index $m$ into the utility function and write the utility function as

$$
u_{m i j}=\delta_{m j}+\mu_{m i j}+\epsilon_{m i j}
$$

where $\delta_{m j}$, the mean utility of product $j$ in market $m$, is the same for all the households in market $m$. The mean utility from the outside alternative is normalized to zero. $\mu_{m i j}$ is the household specific utility. The mean utility is specified as follows

$$
\delta_{m j}=\delta_{j}+X_{m j} \gamma+e_{m j}
$$

where $\delta_{j}$ is a product dummy, absorbing the utility that is constant for all households across the markets (including the utility derived from the unobserved product attributes $\left.\xi_{j}\right) .{ }^{16} X_{m j}$ is a vector of product attributes that vary across MSAs. It includes dollars per mile (DPM), which is the gasoline price in market $m$ divided by the MPG of product $j$. DPM captures the operating cost of the vehicle. $e_{m j}$ is the part of the mean utility that is unobserved to us.

$m u_{m i j}$ is the household specific utility. Following notations in equations (2) and (3), the household specific utility is:

$$
\mu_{m i j}=\alpha_{i} \frac{p_{i j}}{y_{i}}+\sum_{k r} x_{m j k} z_{i r}^{h} \beta_{k r}^{o}+\sum_{k} x_{m j k} \nu_{i k} \beta_{k}^{u}
$$

The household specific utility for the outside alternative is defined by equation (4). Denote the parameters in the mean utility as $\theta_{1}=\left\{\delta_{j}, \gamma\right\}$, and the parameters in the household

\footnotetext{
${ }^{15}$ TAXSIM and an introduction by Feenberg and Coutts (1993) are available at http://www.nber.org/taxsim.

${ }^{16}$ Following equations (2) and (3), $\delta_{j}=\sum_{k} x_{j k} \bar{\beta}_{k}+\sum_{k n} x_{j k} z_{n} \beta_{k n}+\xi_{j}$. Although the parameters from this equation can be estimated once we recover $\delta_{j}$, they are not of our interest in this paper.
} 
specific utility as $\theta_{2}=\left\{\alpha, \beta_{k r}^{o}, \beta_{k}^{u}, \beta_{0}, \beta_{0}^{u}\right\}$.

In estimating the demand model, a key identification problem arises from the correlation between the vehicle prices and unobserved product attributes, which are represented by a latent variable $\xi_{j}$. Since better product attributes often command a higher price, failure to take into account the unobserved product attribute often leads to omitted variable bias in the estimate of price coefficient, suggesting that consumers are less price sensitive than they really are (Trajtenberg (1989); Berry et al. (1995); Petrin (2002); Goolsbee and Petrin (2004)). A common, although strong, identification assumption is that the unobserved product attribute is uncorrelated with observed product attributes. Similar to Nevo (2001), we avoid invoking this assumption by using product dummies to absorb the unobserved product attribute and observed product attributes that are constant across MSAs.

We, nevertheless, make the assumption that the error term in the mean utility function, $e_{m j}$, is uncorrelated with market-varying attributes, $X_{m j}$. Because we only observe vehicle prices (i.e., MSRP) at the national level, $e_{m j}$ may capture local price variations and promotions. $e_{m j}$ may also contain other unobservables such as driving conditions that affect consumers' vehicle preferences. If these local unobservables vary systematically with vehicle fuel economy, the coefficient on DPM is biased downward, suggesting consumers are less sensitive to vehicle fuel cost than what they really are. ${ }^{17}$ In the estimation, we include interaction terms between MSA dummies and vehicle types, such as those between MSA dummies and a dummy variable for hybrid models, to control for these local unobservables.

$\theta_{1}$ and $\theta_{2}$ can be estimated simultaneously by matching the predicted market shares based on our demand model with observed market shares. However, the large number of product dummies renders this approach impractical because the within-group demeaning method as a way to estimate fixed-effect models cannot be applied in this nonlinear framework. Instead, we estimate the model following an iterative two-stage procedure.

\footnotetext{
${ }^{17}$ An example would be that dealers in an area with high gasoline prices may offer deeper discounts for fuel-inefficient vehicles than those in an area with low gasoline prices.
} 
The first stage uses a contracting mapping technique to recover the mean utility $\delta_{m j}$ for each product in each market as a nonlinear function of $\theta_{2}$. BLP shows that under some mild conditions, for a given a $\theta_{2}$, there exists a unique vector of mean utility $\delta_{m j}$ that equates the observed market shares in a given market to the predicated market shares. For a given $\theta_{2}$, the unique vector of mean utilities for market $m, \delta_{m}$, can be recovered using a fixed point iteration:

$$
\delta_{m}^{n+1}=\delta_{m}^{n}+\ln \left(S_{m}^{o}\right)-\ln \left[S_{m}\left(\delta_{m}^{n}, \theta_{2}\right)\right]
$$

where $n$ is the number of iterations; $S_{m}^{o}$ is the vector of observed market shares in market $m$ while $S_{m}$ is the vector of predicted market shares.

The second stage is a simulated GMM with two sets of moment conditions that are formed based on recovered mean utilities from the first stage for any given $\theta_{2}$. The first set of moment conditions is from the exogeneity assumption in equation (12) that $e_{m j}$ is mean independent of $X_{m j}$. From equation (12), $e_{m j}$ can be written as a function of $\theta_{1}$ and $\delta_{m j}$, which is recovered as a function of $\theta_{2}$ from the first stage. Our first set moment conditions $\mathrm{M}_{1}$ is based on:

$$
\mathrm{E}\left[e_{m j}\left(\theta_{1}, \theta_{2}\right) \mid X_{m j}\right]=0 .
$$

The second set, $\mathrm{M}_{2}$, includes 17 micro-moments which match the model predictions to the observed conditional means from the 2001 NHTS as shown in Tables 5 and 6 . For example, we match the predicted probability of new vehicle purchase among households with income less than $\$ 15,000$ to the observed probability in the data.

$$
\mathrm{E}\left[\operatorname{Pr}_{i}(j \neq 0) \mid\left(y_{i}<15,000 ; \delta_{m}\left(\theta_{2}\right), \theta_{2},\right)\right]=0.002 \text {. }
$$

With an initial value of $\theta_{2}$, we recover $\delta_{m j}$ using the contraction mapping. We form the objective function by stacking the two sets of moment conditions which are functions of the initial value of $\theta_{2}$ and the recovered $\delta_{m j}$ as a function of $\theta_{2}$. The GMM estimators 
$\hat{\theta_{1}}$ and $\hat{\theta_{2}}$ minimizes:

$$
\mathrm{J}=\mathrm{M}\left(\theta_{1}, \theta_{2}\right)^{\prime} \mathrm{WM}\left(\theta_{1}, \theta_{2}\right)=\left(\begin{array}{c}
\mathrm{M}_{1}\left(\theta_{1}, \theta_{2}\right) \\
\mathrm{M}_{2}\left(\theta_{2}\right)
\end{array}\right)^{\prime}\left(\begin{array}{cc}
\mathrm{W}_{1} & 0 \\
0 & \mathrm{~W}_{2}
\end{array}\right)\left(\begin{array}{c}
\mathrm{M}_{1}\left(\theta_{1}, \theta_{2}\right) \\
\mathrm{M}_{2}\left(\theta_{2}\right)
\end{array}\right)
$$

The procedure involves iteratively updating $\theta_{2}$ and then $\delta_{m j}$ to minimize the objective function. We start with using the identity matrix as the weighting matrix to obtain consistent initial estimates of the parameters and optimal weighting matrix. We then estimate the model using the new weighting matrix.

With the estimation of the demand side, we can recover the marginal cost for each model based on firms' first order condition for profit maximization in equation (9). The first order condition can also be used to simulate new equilibrium prices in the counterfactual scenarios. We perform two sets of simulations for each counterfactual scenario. One set employs constant marginal cost assumption and the other is based on the estimated relationship between the marginal cost and production. Because U.S. domestic sales of a model often do not coincide with total production of the model due to international trade and data on model-level production are not readily available, we use vehicle sales as the proxy for production in the case of non-constant marginal costs and specify the marginal cost of model $j$ as the following:

$$
m c_{j}=\omega_{j} \rho+\zeta_{j}
$$

where $\omega_{j}$ includes model attributes and U.S. sales. $\zeta_{j}$ is the error term which may include production cost from unobserved product attributes and productivity shock as well.

An endogeneity problem arises in estimating the non-constant marginal cost function given that sales are related to unobserved product attributes. To control for the endogeneity problem, we employ the commonly used identification assumption in the differentiated product literature that unobserved product attributes are mean independent of observed product attributes. Based on this assumption, valid instruments for vehicle sales are pro- 
vided by the observed attributes of other products. These exclusion restrictions arise naturally in a differentiated-product market, where the level of product differentiation is an important factor in determining equilibrium price and quantity. However, the large number of vehicles offered in the U.S. market yields more instruments than we can directly apply. We construct two "distance" measures for each product as parsimonious instruments for vehicle sales following Li (2006). The distance measures reflect how differentiated a product is from other products within the firm and outside the firm. The measures are based on distances between two products in a Euclidean space where different weights are applied to different dimensions of the product-characteristics space. The weights are the coefficients of the corresponding product attributes in a hedonic price regression.

\section{Estimation Results}

We first report parameter estimates and then use these estimates to calculate price elasticities and implied markups for selected products. Table 7 presents the estimates of the parameters in the mean utility as shown in equation (12). We include product fix effects which absorb the part of the mean utility $\delta_{m j}$ that is constant across MSAs. The coefficient on DPM is negative and estimated precisely, reflecting that consumers' vehicle purchase decisions respond to the fuel cost from operating a vehicle. A vehicle with better fuel efficiency hence smaller DPM is valued more than a less fuel-efficient vehicle, ceteris paribus. The identification of this coefficient is based on the cross-MSA sales variation in response to differences in gasoline prices across MSAs: a fuel-efficient vehicle should be more popular in a high gasoline price area than otherwise, all else equal. The variable, local support dummy, equals to 1 for the hybrid models in MSAs where local government supports such as HOV lane privilege and free meter parking are available for hybrid purchases. The coefficient on this variable is positive and significant, suggesting a positive correlation between state and local incentives and the diffusion of hybrid vehicles.

The interaction terms between MSA dummies and the hybrid dummy capture unob- 
served heterogeneity on hybrid demands that may arise from differences in dealer availability and consumer attitudes toward hybrid vehicles. Based on these parameter estimates, consumers in Seattle, San Francisco and San Diego have the strongest incentives to buy hybrid vehicles. We include interactions terms between MSA dummies and vehicle type dummies (i.e., car, SUV, van and pickup truck) to control for unobserved heterogeneity in consumer preference for each type of vehicles across MSAs. For example, consumers in MSAs with more snow and slippery driving conditions might prefer SUVs and pickup trucks, which are often equipped with four-wheel-drive.

Table 7: Parameter estimates in the mean utility

\begin{tabular}{lcc}
\hline \hline Variables & Para. & Std. Err. \\
\hline Dollars per mile (DPM) & -4.110 & 0.425 \\
Local support dummy & 1.635 & 0.275 \\
MSA dummy * Hybrid dummy & & \\
(base group: Albany, NY) & & \\
Albuquerque, NM & -1.477 & 1.469 \\
Atlanta, GA & -1.171 & 0.517 \\
Cleveland, OH & -1.816 & 0.533 \\
Denver, CO & -2.625 & 0.521 \\
Des Moines, IA & -0.244 & 0.504 \\
Hartford, CT & -1.559 & 0.353 \\
Houston, TX & -2.722 & 0.600 \\
Lancaster, PA & -0.828 & 0.490 \\
Las Vegas, NV & 0.367 & 0.650 \\
Little Rock, AR & -2.387 & 1.405 \\
Madison, WI & -0.206 & 0.538 \\
Miami, FL & -0.384 & 0.468 \\
Milwaukee, WI & -0.949 & 0.445 \\
Nashville, TN & -0.759 & 0.478 \\
Phoenix, AZ & -1.429 & 0.519 \\
St. Louis, MO & -2.113 & 0.479 \\
San Antonio, TX & -0.458 & 0.466 \\
San Diego, CA & 0.443 & 0.484 \\
San Francisco,CA & 0.708 & 0.428 \\
Seattle, WA & 0.825 & 0.369 \\
Syracuse, NY & -1.379 & 0.458 \\
MSA dummy * Segment dummy (84) & Yes & \\
Product Fixed Effects (1619) & Yes & \\
\hline & &
\end{tabular}

In table 8 , we present the estimates of the parameters in the household specific util- 
ity defined by equation (13). These parameters capture consumer heterogeneity due to observed and unobserved household demographics. The first four coefficients capture consumer heterogeneity in preference for vehicle price. The coefficient for high income groups being larger implies richer households are less price sensitive. The second four parameters are for the interaction terms between household size and vehicle type dummies. These interaction terms allow families with different household size to have different tastes for a certain type of vehicle. A positive and significant coefficient estimate on the interaction term between household size and van dummy means that the utility from a van increases with household size, ceteris paribus. We also interact house tenure with vehicle type dummies. The last three coefficients being negative and significant suggests that a household in a rented house values van, SUVs and pickup trucks less than those living in their own houses. The estimate of the term interacting the outside alternative with the children dummy suggests that households with children value a new vehicle more than those without. So do those households with a younger household head and those whose commuting time is longer.

Table 8 then reports the estimates of eight random coefficients, which measure the dispersion of heterogeneous consumer preference. These coefficients are the standard errors of consumer preferences for the corresponding product attributes, while the means of consumer preference are presented in table 7. For example, the preference parameter on DPM has a standard normal distribution with mean -4.110 and standard error 2.250. Therefore, 90 percent of the households have a preference parameter on DPM in the range of $[-7.823,0.398]$. The random coefficients ultimately break the independence of irrelevant alternatives (IIA) property of standard logit models in that the introduction a new model into the choice set will draw disproportionately more consumers to the new model from similar products than from others.

Based on our demand and supply estimations, we compute demand elasticities with respect to price and markups. The markup for product $j$ is defined as $\frac{p_{j}-m c_{j}}{p_{j}}$, where $p_{j}$ and $m c_{j}$ are the price and the marginal cost of product $j$, respectively. Table 9 reports 
Table 8: Parameter estimates in household specific utility

\begin{tabular}{lrr}
\hline \hline Variable & Para. & Std. Err. \\
\hline Price/Income if income $\leq 25,000$ & -43.308 & 3.545 \\
Price/Income if income $\leq 50,000 \&$ income $>25,000$ & -39.714 & 2.790 \\
Price/Income if income $\leq 100,000$ \& income $>50,000$ & -34.040 & 4.041 \\
Price/Income if income $>100,000$ & -27.263 & 9.249 \\
Household size * car dummy $^{*}$ van dummy & -1.340 & 0.572 \\
Household size ${ }^{*}$ SUV dummy & 5.629 & 0.407 \\
Household size ${ }^{*}$ pickup dummy & -1.362 & 0.626 \\
Household size ${ }^{*}$ car dummy & -0.293 & 1.540 \\
Rented house ${ }^{*}$ vanted hoummy & -1.252 & 1.530 \\
Rented house ${ }^{*}$ SUV dummy & -14.461 & 3.233 \\
Rented house ${ }^{*}$ pickup dummy & -4.353 & 1.606 \\
Education * hybrid dummy & -7.841 & 4.434 \\
Children dummy ${ }^{*}$ outside good & 0.312 & 0.828 \\
Head age ${ }^{*}$ outside good & -4.968 & 1.489 \\
Travel time outside good & 0.078 & 0.029 \\
Random Coefficient & -0.086 & 0.025 \\
Hybrid dummy & & \\
Log(miles per dollar) & 1.495 & 0.224 \\
Log(horse power) & 2.250 & 0.537 \\
Log(size) & 6.774 & 0.230 \\
Car dummy & 1.495 & 0.224 \\
Van dummy & 9.460 & 0.688 \\
SUV dummy & 26.479 & 1.795 \\
Pickup dummy & 4.901 & 0.621 \\
Outside good & 54.061 & 3.336 \\
\hline
\end{tabular}

own price elasticities and markups for selected products in 2006. One obvious pattern from this table is that within a vehicle class, the demand for cheaper products tends to be more price sensitive. ${ }^{18}$ Among these 14 products, the two most expensive products, Mercedes-Benz E class and Cadillac Escalade, have the highest markup of 21.80\% while the cheapest product, Ford Escort, has the lowest markup of only $8.62 \%$. Interestingly, among three hybrid models, Toyota Prius, although being the cheapest, has the smallest price sensitivity and highest markup. ${ }^{19}$ both elasticities and markups. Among all the

\footnotetext{
${ }^{18}$ Contrary to our finding from the random coefficient specification, a logit model would predict that expensive products tend to be more price elastic.

${ }^{19}$ To the extent that some consumers advertise themselves as environmentalists by driving hybrid vehicles, Prius's distinct appearance makes the model less substitutable than other hybrid models such as
} 
Table 9: Price elasticities and markups

\begin{tabular}{lrrrr}
\hline \hline Products in 2006 & Price & Elasticities & Markups (in \%) & U.S. Sales \\
\hline CARS & & & & \\
Ford Focus & 15,260 & -13.75 & 8.62 & 177,006 \\
Toyota Camry & 19,855 & -9.85 & 12.12 & 417,104 \\
BMW 325 & 31,595 & -7.69 & 14.38 & 120,180 \\
Mercedes-Benz E class & 51,825 & -5.23 & 21.80 & 50,195 \\
VANS & & & & \\
Kia Sedona & 23,665 & -12.16 & 9.13 & 57,018 \\
Honda Odyssey & 25,895 & -8.27 & 12.98 & 177,919 \\
PICKUPS & & & & \\
Ford Ranger & 18,775 & -14.99 & 7.96 & 92,420 \\
Toyota Tacoma & 28,530 & -6.92 & 16.85 & 178,351 \\
SUVS & & & & \\
Honda CR-V & 22,145 & -12.22 & 9.36 & 170,028 \\
Jeep Grand Cherokee & 28,010 & -11.11 & 10.83 & 139,148 \\
Cadillac Escalade & 57,280 & -6.15 & 21.80 & 62,206 \\
HYBRIDS & & & & \\
Toyota Prius & 22,305 & -7.61 & 16.39 & 106,971 \\
Toyota Camry Hybrid & 25,900 & -10.87 & 12.17 & 31,341 \\
Toyota Highlander & 34,430 & -8.10 & 15.51 & 31,485 \\
\hline
\end{tabular}

products, the sales weighted average price elasticity is -10.91 while the average markup is $12.17 \%{ }^{20}$

Table 10 reports the estimation results for the marginal cost function. Bearing in mind that we use U.S. sales as the proxy for total production in order to estimate the relationship between the marginal cost and total production at the model level. Due to the fact that imported models can be very poor proxies for their total production, we use only the models produced in the U.S. to estimate the marginal cost function. These models include those produced by the Big Three and foreign transplants in the U.S. as well. Columns (1) and (2) report coefficient estimates assuming that marginal costs do not change with quantity produced. All the listed coefficient estimates are intuitively signed

Honda Civic which has the same look as the non-hybrid Civic as suggested by Kahn (2008).

${ }^{20}$ Our estimate of average markup is closest to Petrin (2002)'s estimate of 16.7 percent which is based on vehicles sold from 1981 to 1993 including cars, vans and pickup trucks. Goldberg (1995) recovers a much larger estimate of 38 percent for cars from 1983 to 1987 while the average benchmark markup in BLP is estimated as 23.9 percent for cars sold between 1971 and 1990. We have about 200 models each year while Petrin (2002) 185 models, Goldberg (1995) and BLP each have about 110 models per year. 
and all of them except the coefficient on size are significant at the $10 \%$ significance level.

Table 10: Marginal cost function

\begin{tabular}{lcccccc}
\hline \hline Variable & \multicolumn{2}{c}{ Constant MC-OLS } & \multicolumn{2}{c}{ Non-constant MC-OLS } & \multicolumn{2}{c}{ Non-constant MC-IV } \\
& Parameter & Std. Err. & Parameter & Std. Err. & Parameter & Std. Err. \\
& $(1)$ & $(2)$ & $(3)$ & $(4)$ & $(5)$ & $(6)$ \\
\hline Log (sales in 10,000) & & & -0.763 & -0.077 & -1.078 & -0.432 \\
Constant & -6.890 & 2.522 & -6.875 & 2.386 & -6.868 & 2.410 \\
Size & 0.107 & 0.176 & 0.270 & 0.168 & 0.337 & 0.192 \\
HP & 0.473 & 0.032 & 0.450 & 0.030 & 0.440 & 0.033 \\
MPG & 1.078 & 0.494 & 1.337 & 0.468 & 1.444 & 0.495 \\
Weight & 0.372 & 0.067 & 0.345 & 0.064 & 0.334 & 0.066 \\
Segment dummies (14) & Yes & Yes & Yes & Yes & Yes & Yes \\
Year dummies (7) & Yes & Yes & Yes & Yes & Yes & Yes \\
Obs. & 873 & & 873 & & 873 & \\
R-squared & 0.908 & & 0.917 & & & \\
\hline
\end{tabular}

Columns (3) and (4) are the OLS results for non-constant marginal costs while the results in columns (5) and (6) are from the GMM estimation where the endogeneity of $\log$ (sales) is controlled for using product distance measures as instruments. The coefficient estimates on $\log$ (sales) in both regressions being negative means that the marginal cost is decreasing, although at a smaller rate, as production expands. ${ }^{21}$ Compared to the instrument variable regression, the OLS underestimates the coefficient on $\log (\mathrm{sales})$, suggesting a smaller reduction in marginal cost as total production goes up. Because better unobserved product attributes imply a higher marginal cost and at the same time, stronger sales, the observed product attributes bias economies of scale downward in the OLS regression.

\footnotetext{
${ }^{21}$ The J-statistics for over-identification test in the GMM estimation is 0.784 , implying a p-value of 0.367. We assume that the relationship between the marginal cost and production for hybrid models is the same as that for non-hybrid models because we only observe two hybrid models produced in the U.S. in our data. We also estimate the model with a second order of $\log ($ sales). The coefficient on that is positive but not significantly different from zero. This may suggest that firms have not been operating at the production level that exhibits increasing marginal cost during the period under study.
} 


\section{Simulations}

In this section, we conduct counterfactual simulations to address the effect of rising gasoline prices and federal tax incentives on the diffusion of hybrid vehicles. We then conduct simulations to compare the current income tax incentive program with a rebate program in terms of their cost-effectiveness and their effects on industry profits. We solve new equilibrium prices under each scenario based on the estimates of demand parameters and product marginal costs, assuming firms' objectives are to maximize the total period profit from the whole U.S. market. We then estimate new sales for the 22 MSAs under new equilibrium prices. Before presenting the results, it is worthwhile to note that our simulations assume the product offerings would stay the same under different scenarios. ${ }^{22}$ To the extent that both the run-up of the gasoline price and the presence of federal tax incentives strengthen consumer incentives to purchase hybrid vehicles and therefore increase firms' incentive to offer more hybrid models, our static analysis would underestimate the true effects of these two factors.

\subsection{Gasoline Prices}

Understanding how vehicle choice decisions of consumers respond to changes in gasoline prices has important implications for policies that aim to address energy security and environmental problems related to gasoline consumption. Based on our model estimations, we investigate to what extent the recent run-up of gasoline prices contributes to the diffusion of hybrid vehicles. To that end, we simulate what would have happened if gasoline prices from 2000 to 2006 had been the same as those in 1999 level in each of the 22 MSAs.

Columns (1) to (3) in able 11 presents the effects of gasoline price changes on prices of five hybrid models and their non-hybrid counterparts in 2006. The national average

\footnotetext{
${ }^{22}$ The decision of product choice, although an interesting topic, is out of scope of this paper. A serious approach to this topic involves modeling a dynamic game where the model should contend with several key facts about the auto industry: the industry consists of several big players that act strategically, each of them produces multiple products, and products are differentiated.
} 
Table 11: The effect of gas price change on vehicle prices and sales

\begin{tabular}{lcccrrr}
\hline \hline Models in 2006 & $\begin{array}{r}\text { Price } \\
\text { in 2006 } \$ \\
(1)\end{array}$ & $\begin{array}{r}\text { New } \\
\text { Price } \\
(2)\end{array}$ & $\begin{array}{r}\text { Change } \\
\text { in } \% \\
(3)\end{array}$ & $\begin{array}{r}\text { Sales in } \\
22 \text { MSAs } \\
(4)\end{array}$ & $\begin{array}{r}\text { New } \\
\text { Sales } \\
(5)\end{array}$ & $\begin{array}{r}\text { Change } \\
\text { in \% } \\
(6)\end{array}$ \\
\hline Hybrid Models & & & & & & \\
Ford Escape Hybrid & 29,140 & 28,734 & -1.39 & 3,862 & 3,798 & -1.65 \\
Honda Civic Hybrid & 22,400 & 21,662 & -3.29 & 7,232 & 5,883 & -18.65 \\
Honda Accord Hybrid & 31,540 & 31,031 & -1.61 & 1,210 & 1,060 & -12.41 \\
Toyota Highlander Hybrid & 34,430 & 33,319 & -3.23 & 7,594 & 7,552 & -0.55 \\
Toyota Prius & 22,305 & 21,407 & -4.03 & 26,625 & 21,262 & -20.14 \\
Non-hybrid Counterparts & & & & & & \\
Ford Escape & 21,745 & 22,139 & 1.81 & 17,276 & 21,899 & 26.76 \\
Honda Civic & 17,660 & 17,514 & -0.83 & 60,112 & 56,709 & -5.66 \\
Honda Accord & 21,725 & 21,750 & 0.12 & 69,852 & 70,632 & 1.12 \\
Toyota Highlander & 26,535 & 26,841 & 1.15 & 15,684 & 16,789 & 7.05 \\
Toyota Corolla & 15,485 & 15,428 & -0.37 & 74,928 & 74,868 & -0.08 \\
\hline
\end{tabular}

gasoline price was $\$ 1.35$ in 1999 and $\$ 2.53$ in 2006, both in 2006 dollars. $^{23}$ If gasoline prices had stayed at the 1999 level, the five selected hybrid models in 2006 would have been 1.39 to 4.03 percent cheaper as shown in column (3) because they would have been in lower demand given that their saving in fuel cost would be smaller. For their nonhybrid counterparts, the changes in prices are smaller in magnitude. The price of Ford Escape, Honda Accord and Toyota Highlander would have been higher with the gasoline price staying at the 1999 level because they would have been in stronger demand while two more fuel-efficient vehicles, Honda Civic and Toyota Corolla, would have been slightly cheaper.

Columns (4) to (6) show the effect of gasoline price changes on sales. The decrease in sales in the $22 \mathrm{MSAs}$ for the five hybrid models ranges from 0.55 to 20.14 percent have the gasoline price stayed at the 1999 level. The effect on the most efficient hybrid models, Toyota Prius is most significant because buyers of this model are likely to be more sensitive to gasoline prices. On the other hand, without the gasoline price increase in 2006, the sales of regular Ford Escape and Toyota Highlander would have increased by 26.76 and

\footnotetext{
${ }^{23}$ The average gasoline price in the 22 MSAs weighted by vehicle sales was $\$ 1.53$ in 1999 and $\$ 2.60$ in 2006.
} 
7.05 percent, respectively while that of Honda Civic would drop by 5.66 percent.

Table 12: Total hybrid sales in 22 MSAs under the 1999 gas price

\begin{tabular}{lccrrrr}
\hline \hline Year & $\begin{array}{r}\text { Gas price } \\
\text { in 2006 } \$ \\
(1)\end{array}$ & $\begin{array}{c}\text { Price difference } \\
\text { from 1999 }\end{array}$ & $\begin{array}{r}\text { Hybrid Sales } \\
\text { in 22 MSAs }\end{array}$ & New Sales & $\begin{array}{r}\text { Decrease } \\
\text { in Sales } \\
(2)\end{array}$ & $\begin{array}{r}\text { Decrease in } \\
\text { Sales in \% }\end{array}$ \\
\hline 2001 & 1.75 & 0.21 & $(3)$ & $(4)$ & $(5)$ & $(6)$ \\
2002 & 1.54 & -0.01 & 8,461 & 4,888 & 573 & 10.49 \\
2003 & 1.76 & 0.23 & 9,117 & 8,551 & -320 & -3.88 \\
2004 & 2.01 & 0.48 & 17,732 & 15,513 & 304 & 3.33 \\
2005 & 2.41 & 0.88 & 43,658 & 39,757 & 2,146 & 12.10 \\
2006 & 2.6 & 1.07 & 59,059 & 50,776 & 8,901 & 8.94 \\
\hline
\end{tabular}

Table 12 presents the effects of the rising gasoline price on total sales of hybrid vehicles in the 22 MSAs. Column (1) lists the annual average gasoline price weighted by vehicles sales while column (2) gives the increase in gasoline prices in these years relative to that in 1999. Gasoline prices have been continuously increasing over the years except in 2002. In the absence of these increases, hybrid sales would have dropped quite significantly. Although the gasoline price in 2002 stayed the same as that in 1999, the sales of hybrid vehicles would have been less from our simulation. This is due to the fact that gasoline prices have actually dropped in 2002 in several MSAs with strong demand for hybrid vehicles such as San Francisco, San Diego and Seattle. This simulation shows the gasoline price is indeed an important factor in hybrid vehicle purchase decisions. The $\$ 1.07$ price increase in 2006 over the 1999 price explains about 14.02\% of hybrid vehicle sales.

\subsection{Federal Tax Incentives}

Providing tax incentives for hybrid buyers can be justified on the ground that hybrid vehicles emit less pollutants and $\mathrm{CO}_{2}$ and reduce U.S. dependence on foreign oil and that information spillovers among consumers and producers exist in the diffusion of hybrid technology. We now examine the effectiveness of government support on promoting the adoption of hybrid vehicles by removing income tax deductions before 2006 and tax credits in 2006 . 
Table 13: The effect of tax incentives on selected hybrid models

\begin{tabular}{|c|c|c|c|c|c|c|c|}
\hline & \multicolumn{3}{|c|}{ With Incentives } & \multicolumn{4}{|c|}{ Remove Incentives } \\
\hline & \multirow{3}{*}{$\begin{array}{c}\text { Price } \\
\text { (in 2006 \$) } \\
(1)\end{array}$} & \multirow{3}{*}{$\begin{array}{l}\text { Sales in } \\
22 \text { MSAs } \\
(2)\end{array}$} & \multirow{3}{*}{$\begin{array}{r}\text { Tax } \\
\text { Benefit } \\
(3)\end{array}$} & \multicolumn{2}{|c|}{ Price Decrease } & \multicolumn{2}{|c|}{ Sales Decrease } \\
\hline & & & & in $2006 \$$ & in $\%$ & & in $\%$ \\
\hline & & & & & $(5)$ & (6) & (7) \\
\hline \multicolumn{8}{|l|}{2005 Model } \\
\hline Ford Escape Hybrid & 28,330 & 2,918 & 521 & 210 & 0.74 & 181 & 6.20 \\
\hline Honda Civic Hybrid & 20,815 & 4,836 & 513 & 186 & 0.89 & 316 & 6.53 \\
\hline Honda Accord Hybrid & 31,489 & 3,146 & 477 & 216 & 0.69 & 168 & 5.33 \\
\hline Toyota Highlander Hybrid & 33,476 & 3,366 & 418 & 215 & 0.64 & 142 & 4.21 \\
\hline Toyota Prius & 22,106 & 25,528 & 517 & 207 & 0.93 & 1,378 & 5.40 \\
\hline \multicolumn{8}{|l|}{2006 Model } \\
\hline Ford Escape Hybrid & 29,140 & 3,862 & 2,472 & 974 & 3.34 & 1,009 & 26.13 \\
\hline Honda Civic Hybrid & 22,400 & 7,232 & 2,067 & 727 & 3.24 & 1,591 & 22.00 \\
\hline Honda Accord Hybrid & 31,540 & 1,210 & 550 & 245 & 0.78 & 68 & 5.61 \\
\hline Toyota Highlander Hybrid & 34,430 & 7,594 & 1,868 & 852 & 2.47 & 1,406 & 18.52 \\
\hline Toyota Prius & 22,305 & 26,625 & 2,994 & 1,081 & 4.85 & 9,046 & 33.98 \\
\hline
\end{tabular}

Table 13 presents the effects of income tax incentives on both prices and sales of several selected hybrid models in 2005 and 2006. Column (1) shows the price of each model in 2006 dollars and column (2) gives the total sales in the 22 MSAs. Column (3) lists the average tax benefit received by buyers of each model. In 2005, the $\$ 2,000$ tax deduction yields $\$ 521$ income tax return for Ford Escape hybrid buyers on average. In 2006, hybrid buyers are eligible for up to $\$ 2,600, \$ 2,100, \$ 650$ and $\$ 3,150$ tax credit for the purchase of a Ford Escape hybrid, Honda Civic hybrid, Honda Accord hybrid and Toyota Prius, respectively. The tax credit program is more generous for most hybrid models than the tax reduction program. For example, buyers of Ford Escape hybrid on average obtain $\$ 2,472$ income tax return for their purchase in 2006, comparing to only $\$ 521$ in 2005 .

Without tax incentives, both prices and sales of these hybrid models would be reduced. The supply price of a 2005 Ford Escape hybrid would be $\$ 210$ lower as shown in column (4). Comparing with the $\$ 521$ tax benefit received by an average buyer, it suggests that buyers capture about $60 \%$ of the government subsidy and the supplier about $40 \%$. This finding also holds for other hybrid models based on average tax benefits received by buyers 
in column (3) and price decreases in the absence of government subsidy in column (4). ${ }^{24}$ The effect of tax incentives on hybrid vehicle sales in 2005 is less than $7 \%$ for the five hybrid models shown in the table. However, the effect of more favorable tax incentives in 2006 is much more significant: for 2006 Toyota Prius, about $34 \%$ of its sales can be attributed to the tax credit policy in place.

Table 14: The effect of tax incentives on hybrid adoption from 2001 to 2006

\begin{tabular}{lrrrrr}
\hline \hline Year & $\begin{array}{r}\text { Total Subsidy } \\
\text { (in 2006 \$1,000) }\end{array}$ & $\begin{array}{r}\text { Subsidy per } \\
\text { vehicle (in 2006 \$) }\end{array}$ & $\begin{array}{r}\text { Hybrid Sales } \\
\text { in 22 MSAs }\end{array}$ & $\begin{array}{r}\text { Sales w/o } \\
\text { Incentives }\end{array}$ & $\begin{array}{r}\text { Sales Decrease } \\
\text { in \% }\end{array}$ \\
\hline 2001 & $(1)$ & $(2)$ & $(3)$ & $(4)$ & $(5)$ \\
2002 & 3,489 & 639 & 5,461 & 5,014 & 8.19 \\
2003 & 5,023 & 610 & 8,231 & 7,558 & 8.18 \\
2004 & 4,966 & 545 & 9,117 & 8,346 & 8.46 \\
2005 & 9,408 & 531 & 17,732 & 16,476 & 7.08 \\
2006 & 21,435 & 491 & 43,658 & 41,387 & 5.20 \\
\hline
\end{tabular}

Table 14 presents the effect of tax incentives on total hybrid sales in the 22 MSAs from 2001 to 2006. Column (1) lists the total government subsidy for hybrid vehicle purchases over the period. Column (2) presents average tax returns received by hybrid buyers in 2006 dollars. They are decreasing from 2001 to 2005 due to two facts. First, while the tax deduction is kept at $\$ 2,000$, the inflation is about $14 \%$ over this period. Second, the number of households subject to Alternative Minimum Tax (AMT) increases significantly. These households are not eligible for the tax benefit when buying hybrid vehicles. In 2006, government support, in the form of tax credits, is much stronger: the tax benefit received by each hybrid buyer is $\$ 2,432$ on average. $26.93 \%$ of the total hybrid sales in the 22

\footnotetext{
${ }^{24}$ Our estimates show that buyers of Toyota Prius in 2006 capture about $65 \%$ of total federal tax incentives. Sallee (2008) estimates that buyers of 2006 Toyota Prius get at least $73 \%$ of total tax subsidies using detailed retail price data. In order to explain the finding that consumers capture the significant majority of the benefit from federal tax subsidies in the case of Toyota Prius, whose production was capacity constrained in 2006, he suggests a model where current vehicle prices influence future demand (e.g., due to goodwill). Allowing the intertemporal price effect in our model would intuitively increase the percentage of benefit captured by consumers. Moreover, allowing decreasing marginal cost as we do in our following analysis would also generate the case where consumers capture a higher percentage of tax incentives.
} 
MSAs could be explained by tax credits, comparing to less than $10 \%$ in previous years. It is interesting to note that hybrid sales, although smaller, would still be increasing over time even without tax incentives.

In 2005, U.S. motor gasoline consumption was 9.16 million barrels per day, accounting for about $45 \%$ of total U.S. petroleum consumption. Total $\mathrm{CO}_{2}$ emission from motor vehicle usage was 3.78 million tons per day. ${ }^{25}$ Table 15 presents total reductions in $\mathrm{CO}_{2}$ emission and gasoline consumption in the U.S. over vehicle lifetime (15 years) assuming annual travel of 12,000 miles per vehicle. These reductions arise from the increased sales of hybrid vehicles induced by income tax incentives from 2001 to 2006. Given the small number of hybrid models available and small market share of hybrid vehicles, these reductions have been inconsequential compared to total $\mathrm{CO}_{2}$ emission and gasoline consumption. Nevertheless, the reductions in $\mathrm{CO}_{2}$ emission and gasoline consumption will become more significant with ever increasing number of hybrid models on the market.

Table 15: Total reductions in gas consumption and $\mathrm{CO}_{2}$ emission over vehicle lifetime

\begin{tabular}{ccc}
\hline \hline Year & $\begin{array}{c}\mathrm{CO}_{2} \text { Reduction } \\
\text { in million tons }\end{array}$ & $\begin{array}{c}\text { Gasoline Reduction } \\
\text { in million barrels }\end{array}$ \\
\hline 2001 & 0.11 & 0.26 \\
2002 & 0.19 & 0.45 \\
2003 & 0.18 & 0.42 \\
2004 & 0.42 & 1.00 \\
2005 & 0.68 & 1.62 \\
2006 & 5.14 & 12.24 \\
\hline
\end{tabular}

\subsection{Tax Credit Versus Rebate}

In both income tax deduction and income tax credit programs, households with lower income hence lower income tax lability may not be eligible for the maximum possible incentives. However, these household should be more responsive to tax incentives given that they tend to be more price sensitive. This suggest a rebate program that allows

\footnotetext{
${ }^{25}$ Assuming consumption of one gallon gasoline generates 19.594 pounds of $\mathrm{CO}_{2}$.
} 
equal subsidy across buyers of the same hybrid model may be more cost-effective. ${ }^{26}$ In this section, we compare the income tax credit program with a rebate program, which distributes equal subsidy across households who purchase the same hybrid model and are not subject to AMT. ${ }^{27}$

We also examine the effect of the rebate program on industry profit. With the same amount of government spending, the increase in hybrid prices due to subsidy may be higher in the tax credit program than in the rebate program given that high-income households (less price sensitive) tend to receive more income tax benefits than low-income households under the tax credit program. Therefore, the income tax programs may be more favorable to auto manufacturers than the rebate program.

Table 16: Comparison of the tax credit program with a rebate program in 22 MSAs

\begin{tabular}{lcccc}
\hline \hline & $\begin{array}{c}\text { Average MPG } \\
\text { in 22 MSAs }\end{array}$ & $\begin{array}{c}\text { Total Subsidy } \\
\text { (in 2006 \$Million) }\end{array}$ & $\begin{array}{c}\text { Total Variable Profit } \\
\text { (in 2006 \$Million) }\end{array}$ & $\begin{array}{c}\text { Hybrid Sales } \\
\text { in 22 MSAs }\end{array}$ \\
\hline $\begin{array}{l}\text { Baseline: Current Tax Credit Program } \\
\text { Tax Credit Program }\end{array}$ & 23.19 & 143.65 & & \\
Rebate Program & 23.19 & 138.69 & $8,268.57$ & 59,059 \\
Difference & 0 & $-4.96(-3.5 \%)$ & $8,266.97$ & 58,567 \\
& & & -1.60 & -492 \\
Baseline: Increase Tax Credits by & $\mathbf{\$ 1 , 0 0 0}$ & & \\
Tax Credit Program & 23.34 & 269.84 & $8,275.54$ & 80,517 \\
$\begin{array}{l}\text { Rebate Program } \\
\text { Difference }\end{array}$ & 23.34 & 249.87 & $8,271.91$ & 79,009 \\
& 0 & $-19.97(-7.4 \%)$ & -3.63 & 1,508 \\
\hline
\end{tabular}

Table 16 shows the difference between the income tax credit program and the rebate program in terms of total government subsidy and total industry variable profit. Under the current tax credit program, the average MPG of new vehicles sold in 2006 is 23.19. To reach the same average fuel-efficiency, the rebate program would cost 138.69 million dollars in government revenue, comparing to 143.65 million dollars under the tax credit

\footnotetext{
${ }^{26}$ Another benefit of such a rebate program is analogous to that in income transfer from high-income households to low-income households, which can be measured by changes in total consumer welfare. We do not quantify this benefit here.

${ }^{27}$ In recent years, more and more households in the top income quartile have been subject to AMT, which disqualifies these household for the tax incentives. In the tax rebate program, we assume that households subject to AMT are not eligible for the rebate, either.
} 
program. Meanwhile, total industry variable profit from the 22 MSAs, defined as total revenue minus total variable costs, would decrease slightly in the rebate program. Even thought both programs reach the same level of average fuel-efficiency, there are slightly fewer hybrid models sold in the rebate program, reflecting a stronger demand from lowincome households for Toyota Prius and Honda Civic, two cheapest and most fuel-efficient hybrid models. The rebate program would save about $3.5 \%$ in government subsidy. The small magnitude is mainly due to the fact that under the current tax credit program, only families with low income are not able to enjoy full tax incentives due to their low tax liabilities and that the proportion of these households purchasing new vehicles is very small. However, if the tax credit were to be increased or income tax credits for other energy-efficient products are to be considered simultaneously in consumers' vehicle purchase decisions, more households would be constrained by their tax liabilities in getting tax benefit from purchasing hybrid vehicles. Therefore, the rebate program would exhibit a stronger advantage over the tax credit program. The difference between a more generous tax credit program and a tax rebate program is shown in the second panel of the table where we increase the tax credit for each hybrid model by $\$ 1,000 .^{28}$ The average fuelefficiency increases to 23.34 MPG and the number of hybrid models sold increases to 80,517 with higher tax credits. For the average MPG of new vehicles to reach 23.34, the rebate program would need 249.87 instead of 269.84 million dollars. This represents a $7.4 \%$ reduction in government subsidy to hybrid vehicle buyers.

\subsection{Non-constant Marginal Costs}

In this section, we investigate the robustness of our previous findings with respect to the assumption of marginal costs. To that end, we conduct simulations based on our estimation of the non-constant marginal cost function. One caveat of these simulation results is that the marginal cost function is estimated using U.S. sales as proxies for total

\footnotetext{
${ }^{28}$ The Energy Policy Act of 2005 includes tax credits for many types of energy-efficient products. The maximum amount of credit for qualified home improvements combined is $\$ 500$ during the two year period of 2006 and 2007. Moreover, a tax credit, up to $\$ 2,000$, is available for qualified solar energy systems.
} 
model production. Although in the estimation of the marginal cost function, we use only domestically produced models (their U.S. sales may be good proxies for their total production), we have to use U.S. sales for all the models as proxies for their total output levels in the simulations due to the lack of production data. To the extent that U.S. sales of imported models account for a smaller share of their total production than domestically produced models, the simulation results for imported models overestimate the reduction in their marginal costs from the increased sales given that the marginal cost function decreases at a decreasing rate with the output level.

Table 17 compares the effects of the recent run-up in gasoline prices on hybrid vehicle demand under two different scenarios of marginal costs. The first two columns are the observed prices and sales in 22 MSAs. Columns (3) and (4) are the simulated prices and sales for the case of constant marginal costs while columns (5) and (6) present simulated prices and sales for the case of non-constant marginal costs had gasoline prices stay at the 1999 level. The comparison between columns (4) and (6) shows that the effect of the increase in gasoline prices on sales is stronger in case of non-constant marginal cost because the larger sales of hybrid models due to higher gasoline prices reduce their marginal costs, which in turn pushes the sales even larger. The same reason, however, causes the price increases of hybrid models due to higher gasoline price to be smaller in the case of nonconstant marginal costs as shown in columns (3) and (5).

Table 17: Comparison of the effects of gasoline prices

\begin{tabular}{lcccccc}
\hline \hline Hybrid Models & \multicolumn{2}{c}{ Observed } & \multicolumn{2}{c}{ Constant MC } & \multicolumn{2}{c}{ Non-constant MC } \\
in 2006 & Price in & Sales in & Price in & Sales in & Price in & Sales in \\
& $2006 \$$ & 22 MSAs & $2006 \$$ & 22 MSAs & $2006 \$$ & 22 MSAs \\
& $(1)$ & $(2)$ & $(3)$ & $(4)$ & $(5)$ & $(6)$ \\
\hline Ford Escape & 29,140 & 3,862 & 28,734 & 3,798 & 28,771 & 3,781 \\
Honda Civic & 22,400 & 7,232 & 21,662 & 5,883 & 21,926 & 5,391 \\
Honda Accord & 31,540 & 1,210 & 31,031 & 1,060 & 31,098 & 1,019 \\
Toyota Highlander & 34,430 & 7,594 & 33,319 & 7,552 & 33,463 & 7,117 \\
Toyota Prius & 22,305 & 26,625 & 21,407 & 21,262 & 21,674 & 19,411 \\
\hline
\end{tabular}

Table 18 compares the effects of gasoline price changes and tax incentives on total 
sales of hybrid vehicles in 22 MSAs under two different assumptions about marginal costs. With decreasing marginal costs, the effects are stronger. ${ }^{29}$ The increase in gasoline price in 2006 over its 1999 level explains more than 17\% of hybrid vehicle sales instead of $14 \%$ estimated under constant marginal cost; while the income tax credit accounts for about $32 \%$ of hybrid vehicle sales instead of $27 \%$.

Table 18: The effects on total hybrid vehicle sales in 22 MSAs

\begin{tabular}{cccccc}
\hline \hline Year & $\begin{array}{c}\text { Total Sales } \\
\text { in 22 MSAs }\end{array}$ & \multicolumn{5}{c}{ Sales Change in \% Due to } \\
& & Constant MC & Non-constant MC & Constant MC & Non-constant MC \\
& $(1)$ & $(2)$ & $(3)$ & $(4)$ & $(5)$ \\
\hline 2001 & 5,461 & 10.49 & 10.90 & 8.19 & 11.61 \\
2002 & 8,231 & -3.88 & -3.44 & 8.18 & 11.39 \\
2003 & 9,117 & 3.33 & 4.81 & 8.46 & 11.31 \\
2004 & 17,732 & 12.10 & 13.94 & 7.08 & 9.11 \\
2005 & 43,658 & 8.94 & 10.58 & 5.20 & 6.65 \\
2006 & 59,059 & 14.02 & 17.42 & 26.93 & 32.16 \\
\hline
\end{tabular}

We also examine the cost-effectiveness of the income tax credit program and the flat rebate program with decreasing marginal costs. The results are almost identical to those with constant marginal costs. For example, to reach the same level of average MPG under the income tax credit program in the 22 MSAs in 2006, the rebate program needs $\$ 4.97$ million less government funding in the case of decreasing marginal costs compared to $\$ 4.96$ million less in the case of constant marginal costs. This finding is mainly due to the way in which we measure the cost-effectiveness. In order to reach the same level of fleet fuel-efficiency, almost the same number of hybrid vehicles are sold under two different government programs. Therefore, whether marginal costs are constant or not with respect to the output level does not affect the comparison results of these two programs.

As outline in the National Energy Policy Report (2001), one of the purposes of sub-

\footnotetext{
${ }^{29}$ One exception is in year 2002. This is due to the fact that although the average gasoline price in the 22 MSAs in 2002 was lower than that in 1999 (implying stronger demand for hybrid vehicles in 22 MSAs under the 1999 gasoline price), the opposite was true for the average gasoline price in the whole country (implying weaker demand for hybrid vehicles in the national market, which is the basis for firms' profit maximization problem and hence the computation of new equilibrium prices).
} 
sidizing hybrid vehicle purchase is to help manufacturers achieve economies of scales and reduce the production cost of hybrid vehicles. From the marginal cost function estimation, we find that the marginal cost of vehicle production decrease with respect to output. ${ }^{30}$ Based on the marginal cost function, we can examine the extent to which government support programs reduce the variable cost of hybrid vehicle production. ${ }^{31}$

Table 19 reports the reduction in the average variable cost (AVC) of five of the hybrid models in 2006 brought about by the federal income tax credit program. Columns (3) and (4) are total U.S. sales for each model with and without the income tax incentive, respectively. The increase in U.S. sales due to the tax incentive ranges from $15 \%$ to $30 \%$. The last column reports the reduction in AVCs from the increases in sales. The production of Toyota Prius enjoyed the largest reduction in the AVC due to the largest increase in sales among these hybrid models. The results show that the $\$ 3,000$ income tax credit on the purchase of a Prius brought its AVC down by $\$ 421$ in 2006.

Table 19: Reductions in the average variable cost for selected models

\begin{tabular}{|c|c|c|c|c|c|}
\hline Year & Hybrid Model & $\begin{array}{c}\text { Price in } \\
2006 \$ \\
(2)\end{array}$ & U.S. Sales & $\begin{array}{r}\text { U.S. Sales } \\
\text { w/o Subsidy } \\
(4)\end{array}$ & $\begin{array}{r}\text { Reduction in } \\
\text { AVC in } \$ \\
(5)\end{array}$ \\
\hline 2006 & Ford Escape & 29,140 & 19,375 & 15,321 & 224 \\
\hline 2006 & Honda Civic & 22,400 & 31,253 & 23,401 & 289 \\
\hline 2006 & Honda Accord & 31,540 & 5,598 & 5,268 & 41 \\
\hline 2006 & Toyota Highlander & 34,430 & 31,485 & 25,709 & 203 \\
\hline 2006 & Toyota Prius & 22,305 & 106,971 & 71,694 & 421 \\
\hline
\end{tabular}

Table 20 presents the decreases in the variable cost of hybrid vehicles over time due to the federal income tax incentive programs. Columns (1) to (3) report, respectively, the weighted average price, subsidy, and reduction in the AVC for hybrid vehicles in each

\footnotetext{
${ }^{30}$ Because most of the hybrid models are imported and their U.S. sales may not be good proxies for their total production, we are not able to estimate a separate relationship between the marginal cost and the output level for hybrid vehicles.

${ }^{31}$ Given the high fixed cost in auto manufacturing, economies of scale can still arise even if the marginal cost of production is constant. However, without observing the fixed cost, we are not able to estimate the decrease in the average cost of production induced by the federal tax incentive programs. Our estimates on the decrease in variable costs provide a lower bound for that.
} 
Table 20: Reductions in the variable cost for all hybrid models

\begin{tabular}{ccccrr}
\hline \hline Year & $\begin{array}{c}\text { Average Price per } \\
\text { Hybrid Vehicle } \\
\text { in } 2006 \$\end{array}$ & $\begin{array}{c}\text { Subsidy per } \\
\text { Hybrid Vehicle } \\
\text { in } 2006 \$\end{array}$ & $\begin{array}{c}\text { Reduction } \\
\text { in AVC } \\
\text { in } 2006 \$\end{array}$ & $\begin{array}{c}\text { U.S. Sales } \\
\text { of Hybrids }\end{array}$ & $\begin{array}{r}\text { Reduction in total } \\
\text { variable cost } \\
\text { in million } \$\end{array}$ \\
\hline 2001 & 20,210 & $(2)$ & $(3)$ & $(4)$ & $(5)$ \\
2002 & 19,918 & 639 & 50 & 20,282 & 1.02 \\
2003 & 19,497 & 545 & 57 & 35,961 & 2.06 \\
2004 & 19,294 & 531 & 54 & 44,773 & 4.43 \\
2005 & 23,553 & 491 & 47 & 82,555 & 9.51 \\
2006 & 23,849 & 2,432 & 309 & 251,828 & 77.83 \\
\hline
\end{tabular}

year from 2001 to 2006. The weights are the observed sales of each hybrid model. An average subsidy of $\$ 639$ per hybrid vehicle yielded a $\$ 50$ average reduction in the AVC in 2001 while an average subsidy of $\$ 2,432$ achieved a $\$ 309$ average reduction in the AVC of hybrid models in 2006. Column (5) gives the total reduction in the total variable cost of all hybrid models in each year brought about by the tax incentive programs. The results show that the income credit program cut down the total variable cost of all hybrid vehicles by nearly 78 million dollars in 2006 .

\section{Conclusion}

With rising gasoline prices, unstable petroleum supplies, and growing concern about global climate change and pollution, support for curbing U.S. fuel consumption has increased dramatically in recent years. The hybrid technology is considered as one promising solution to energy security and environmental protection. To promote consumer adoption of hybrid vehicles, the U.S. government has been providing hybrid vehicle buyers income tax incentives to offset the significantly higher cost of hybrid vehicles relative to their nonhybrid counterparts. In this paper, we analyze the determinants in the demand for hybrid vehicles, paying particular attention to the effect of rising gasoline prices and income tax incentives. We also investigate the cost-effectiveness of the current income tax credit program by comparing it to a hypothetical rebate program. 
We find that the gasoline price is indeed an important factor in hybrid vehicle purchase decisions. If the gasoline price in 2006 have stayed at the 1999 level (\$1.53 instead of $\$ 2.60$ on average at the $22 \mathrm{MSAs}$ ), hybrid vehicle sales in 2006 would have been $14 \%$ less. Our results confirm that recent increases in gasoline prices contribute significantly to the increasing market share of hybrid vehicles. Moreover, the availability of income tax incentives is also an important element in the demand for hybrid vehicles. Income tax deductions explain about 5-9\% of hybrid vehicle sales from 2001 to 2005 while more generous income tax credits in 2006 account for about $27 \%$ of hybrid vehicles sales. These findings suggest that in the absence of significant reduction in production costs hence prices of hybrid vehicles, both high gasoline prices and continuous government support may be necessary for further diffusion of hybrid vehicles.

Another finding is that a rebate program that offers enhanced incentives for low-income households compared to the current income tax credit program costs less government revenue in achieving the same average fuel-efficiency of new vehicles. The advantage of a rebate program over an income tax credit program increases with the level of government support. For example, we find that if current tax credits for hybrid models were to be increased by $\$ 1,000$, a rebate program that achieves the same average fuel-efficiency would cost more than $7 \%$ less in government revenue. Although current government support for consumers to adopt energy-efficient products mainly takes the form of income tax credits, our finding calls for wider adoption of flat subsidy programs in future legislations that aim to promote energy conservation and environmental protection. 


\section{References}

Austin, D. and T. Dinan, "Clearing the Air: The Costs and Consequences of Higher CAFE Standards and Increased Gasoline Taxes," Journal of Environmental Economics and Management, 2005, pp. 562-582.

Bento, A., L. Goulder, E. Henry, M. Jacobsen, and R. von Haefen, "Distributional and Efficiency Impacts of Gasoline Taxes: An Econometically-Based MultiMarket Study," American Economic Review, Papers and Proceedings, 2005, 95 (2), $282-287$.

Berry, S., J. Levinsohn, and A. Pakes, "Automobile Prices in Market Equilibrium," Econometrica, July 1995, 63, 841-890.

_ , , and _, "Differentiated Products Demand Systems from a Combination of Micro and Macro Data: The New Car Market," Journal of Political Economy, 2004, 112 (1), 68-105.

Bresnahan, T., "Competition and Collusion in the American Automobile Industry," Journal of Industrial Economics, 1987, 35, 457-482.

Congressional Budget Office, The Economic Costs of Fuel Economy Standards Versus a Gasoline Tax, Washington, DC: Congress of the United States, 2003.

Feenberg, D. and E. Coutts, "An Introduction to the TAXSIM Model," Journal of Plicy Analysis and Management, 1993, 12 (1), 189-194.

Gallagher, K. and E. Muehlegger, "Giving Green to get Green? The Effect of Incentives and Ideology on Hybrid Vehicle Adoption," 2007. Working Paper.

Goldberg, P., "Product Differentiation and Oligopoly in International Markets: The Case of the US Automobile Industry," Econometrica, July 1995, 63, 891-951.

Goolsbee, A. and A. Petrin, "The Consumer Gains from Direct Broadcast Satellites and the Competition with Cable TV," Econometrica, 2004, 72 (2), 351-381. 
Jacobsen, M., "Evaluating U.S. Fuel Economy Standards in a Model with Producer and Household Heterogeneity," 2007. Stanford Job Market Paper.

Jaffe, A. and R. Stavins, "The Energy Paradox and The Diffusion of Conservation Technology," Resource and Energy Economics, 1999, 16, 91-122.

Kahn, Matthew, "Do greens drive Hummers or hybrids? Environmental ideology as a determinant of consumer choice," 2008. forthcoming, Journal of Environmental Economics and Managment.

Li, S., "The Social Costs of the 'Arms Race' on American Road: Evidence from Automobile Demand," 2006. Job Market Paper, Department of Economics, Duke University.

National Research Council, Effectiveness and Impact of Corporate Average Fuel Economy (CAFE) Standards, National Academy Press, 2002.

Nevo, A., "Mergers with Differentiated Products: the Case of the Ready-to-eat Cereals Industry," Econometrica, 2001, (2), 307-342.

Petrin, A., "Quantifying the benefit of new products: the case of minivan," Journal of Political Economy, 2002, 110 (4), 705-729.

Sallee, J., "The Incidence of Tax Credits for Hybrid Vehicles," 2008. University of Michigan Job Market Paper.

Stoneman, P. and P. Diederen, "Technology Diffusion and Public Policy," Economic Journal, 1994, 104 (425), 918-930.

Trajtenberg, M., "The Welfare Analysis of Product Innovations, with an Application to Computed Tomography Scanners," Journal of Political Economy, 1989, 97, 444-479.

West, S. and R. Williams, "The Cost of Reducing Gasoline Consumption," American Economic Review, 2005, (2), 294-299. 